\title{
CALCAREOUS NANNOFOSSIL BIOSTRATIGRAPHY OF LANGHIAN DEPOSITS IN LEFKAS (IONIAN ISLANDS)
}

\author{
Triantaphyllou M. V. ${ }^{1}$ \\ ${ }^{1}$ Department of Historical Geology and Palaeontology, Faculty of Geology and Geoenvironment, \\ University of Athens, Panepistimiopolis 15784,Athens, Greece,mtriant@geol.uoa.gr
}

\begin{abstract}
Spanochorion composite section (NE Lefkas) and Aghios Vassilios section (W Lefkas) have been studied semiquantitatively for their calcareous nannofossil content. The calcareous nannofossil biostratigraphy, performed at the Paxos unit atypical flysch sediments of Aghios Vassilios section, permits their biostratigraphic correlation with the uppermost part of NN4 biozone and the lower part of NN5 biozones (Martini, 1971) or MNN4b and MNN5 (Fornaciari and Rio, 1996), which chronostratigraphically point to Early Langhian age and range between 15.974 and $14.53 \mathrm{Ma}$. The most interesting biostratigraphic result is the detection of the Sphenolithus heteromorphus Paracme End at the base of Aghios Vassilios section, a biohorizon that marks the basal Langhian deposits in the Mediterranean region. The mollasic sediments of Spanochorion section are more or less of the same age, ranging between 15.5 and $14.53 \mathrm{Ma}$. The biostratigraphic results of the present study reinforce the hypothesis that the molassic sediments of NE Lefkas Island behind the Ionian thrust were isochronously deposited with Paxos atypical flysch sequences deposited in front of Ionian thrust, at least until Early Langhian times.
\end{abstract}

Key words: calcareous nannofossils, Langhian, Sphenolithus heteromorphus Paracme Zone.

\section{Introduction}

The geology of Lefkas Island comprises carbonate and clastic sediments which belong to the external geotectonic units of the Hellenic arc; Paxos (Pre-Apulian) and Ionian, ranging between TriassicTortonian and Triassic-Aquitanian respectively (Renz, 1955; Bornovas, 1964). These two units are separated by a major west-directed thrust fault (Aubouin, 1959; Jacobshagen, 1986), marked by evaporate intrusion (Karakitsios and Rigakis, 2007). The current geodynamic regime is expressed by a dense fault network, striking to the NNE-SSW or E-W direction that has overprinted the preexisting thrust-related features and has been dominant throughout the Plio-Quaternary, breaking up the island in a multitude of independent fault blocks (Lekkas et al., 2001).

In particular Lefkas Island consists mainly of the carbonate sequence of the Ionian unit that forms the major part of the island and the limestones of Paxos (Pre-Apulian) unit, at the southwestern part (Lefkata peninsula). The Ionian unit contains (Permo)-Triassic gypsum, Triassic to Jurassic platform carbonates and deep-marine well-bedded limestones that overthrusted the (pre)-Apulian unit. The stratigraphy of the Ionian unit exhibits three distinct sequences (Karakitsios, 1992, 1995); a prerift, a synrift and a postrift sequence. The latter one consists of the Vigla limestones and overlying Alpine formations and is defined by an Early Berriasian breakup at the base. The postrift sequence contin- 

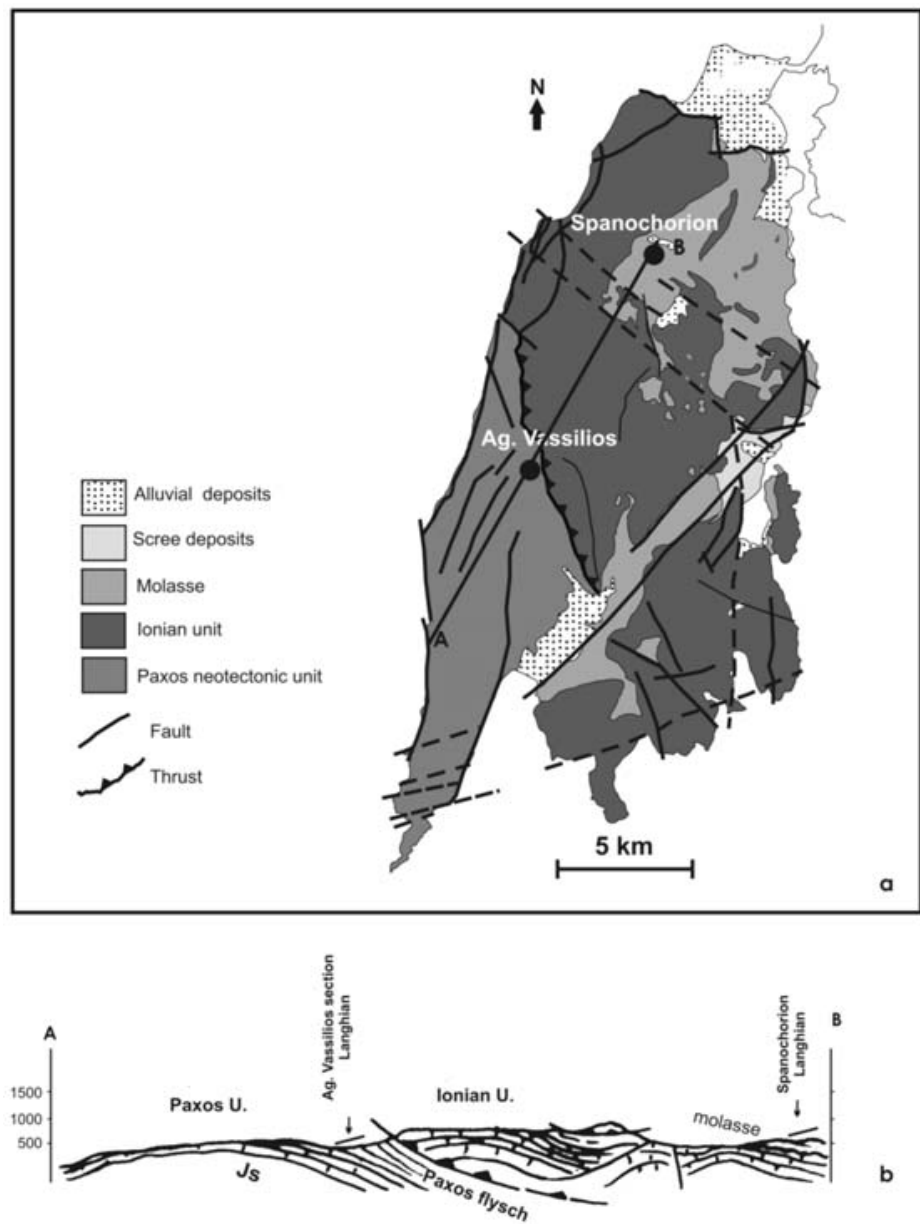

Fig. 1: a. Simplified geological and neotectonic map of Lefkas Island (after Bornovas, 1964, Rondoyanni- Tsiambaou, 1997, Lekkas et al., 2001). Position of the studied sections is indicated by black circles. b. Geological section ( $\mathrm{AB}$ on map) showing the geological position of the studied sections.

ued till the end of the Eocene, followed by the deposition of flysch sediments (Karakitsios, 1992, 1995; Sotiropoulos et al., 2003). The depositional sequence of the Paxos unit in Lefkas Island begins with Lower Jurassic dolomites and Middle Jurassic cherts and bituminous shales (Bornovas, 1964; BP, 1971). During the Campanian-Maestrichtian intra-platform basins characterised the slope between the Apulian platform and the Ionian basin (Nikolaou, 1986; Karakitsios and Rigakis, 2007). Sporadic hiatuses in between Paleocene and Late Cretaceous have been described by Mirkou (1974), suggesting intense tectonic activity, that persisted throughout the Oligocene, suggesting the presence of flexural subsiding foreland basins (Karakitsios and Rigakis, 2007). The Paxos unit exposes Oligocene to Lower Miocene deep-marine carbonate successions, with a transition to terrigenous clastics in the course of the late Burdigalian (late Early Miocene) to early Langhian (early Middle Miocene), (De Mulder, 1975). It has so far been generally accepted that the Paxos (Pre-Apulian) zone lacks typical flysch sediments. However, the observed progressive passage from the Ionian typical fly- 
sch to the more calcareous, age-equivalent, facies in the Pre-Apulian zone (BP, 1971) indicates that post- Oligocene Pre-Apulian sediments correspond to an atypical distal flysch unit (Karakitsios \& Rigakis 2007). It's partial or complete absence from some areas corresponding to the most external part of the forebulge depozone in the Hellenide foreland basin system (sensu DeCelles \& Giles 1996), can be associated with erosional phaenomena (Karakitsios \& Rigakis 2007).

On Lefkas Island, molassic formations of mostly marine Aquitanian-Tortonian (Bornovas, 1964; Lekkas et al., 2001) marls, bioclastic limestones conglomerates and sandstones are unconformably overlying the Ionian sequence and few outcrops of Ionian flysch turbidites (Cushing, 1985; Rondoyanni- Tsiambaou, 1997). The lower parts of the Paxos atypical flysch sequence at western Lefkas, are considered isochronous to the mollasic deposits (Bornovas, 1964; IGRS-IFP, 1966; BP, 1971; Cushing, 1985; Lekkas et al., 2001). Neogene clastic sediments and quaternary coastal deposists consist the post-alpine formations (Bornovas, 1964; IGRS-IFP, 1966; Cushing, 1985).

Little biostratigraphic work has been done in respect to the above mentioned atypical flysch and molassic deposits on Lefkas Island, and their biostratigraphic assignment. De Mulder (1975) provided some constraints on the age of several Oligocene-Miocene outcrops of Lefkas, based mainly on the planktonic foraminiferal biostratigraphy, and suggested that they were extending at least up to Serravallian. Recently, Drinia et al. (2007) have studied the paleobathymetric evolution of the Manassi section at the southwestern part of Lefkas Island. They identified turbidite beds intercalated with in-situ marly sediments and dated these atypical Paxos (Pre-Apulian) flysch deposits as of early Tortonian age, between 11.54-11.2 Ma.

The main scope of the present study is to evaluate by means of calcareous nannofossil biostratigraphy the age of parts of Paxos atypical flysch sediments and molassic deposits on Lefkas Island, and inquire whether their deposition is at least partly isochronous.

\section{Materials and methods}

Ag. Vassilios section in the southwestern part of Lefkas Island (Fig. 1a), about $400 \mathrm{~m}$ in thickness, is located on the eastern slope of a N-S running valley (De Mulder, 1975) and consists of fine grained clayey and marly sediments with some sandy intercalations, assigned to the atypical flysch marly deposits of Paxos unit (Bornovas, 1964; Lekkas et al., 2001). Twenty samples from the lower approximately $100 \mathrm{~m}$ of the section have been investigated for their nannofossil content (Figs 2a, 3).

Section Spanochorion is located along the road to Lazarata village at the northeastern part of the island (Fig. 1a) and represents part of the Spanochorion section described by De Mulder (1975). It consists of about $50 \mathrm{~m}$ of marls alternating with coarse breccious beds and marly limestones. Thirty-three samples have been collected from the fine grained intercalations and studied by the means of calcareous nannofossils (Figs 2b, 4).

Calcareous nannofossil biostratigraphy, mainly based on the appearance/disappearance and relative abundance patterns of selected species, provided high time resolution and accurate correlation with regional and global stratigraphy and time scale for the Miocene marine successions (Fornaciari and Rio, 1996; Lourens et al., 2004; Raffi et al., 2006).

Smear slides for calcareous nannofossil analysis have been prepared following the standard preparation technique of Perch Nielsen (1985). To obtain accurate biostratigraphic estimations, up to 100 fields of view have been investigated per slide, counting at least 500 specimens, with a Leica DMLSP optical polarising light microscope at 1250x. Nannofossil state of preservation was overall very 


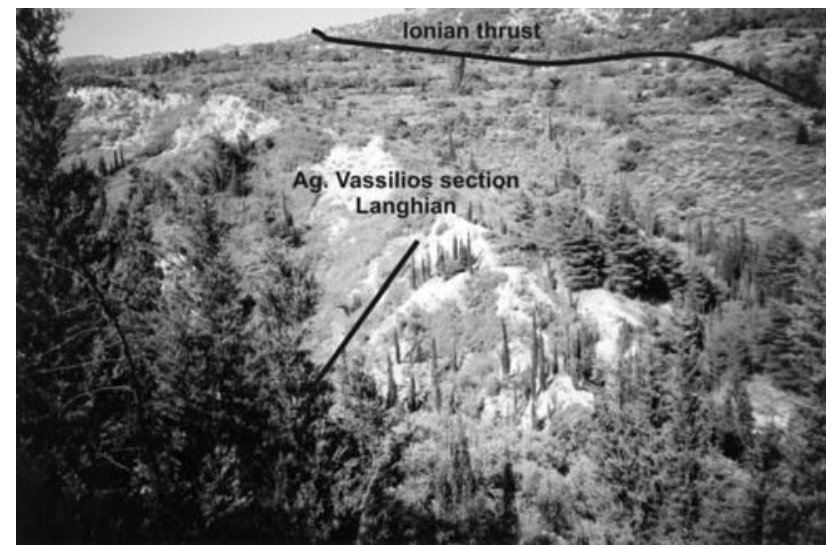

Fig. 2a: Panoramic view of Ag. Vassilios section (Paxos atypical flysch sequence).

good. Semiquantitative abundances of the taxa encountered were recorded as follows: A, abundant: more than one specimen every field of view; C, common: 1 specimen/10 fields of view; $\mathrm{R}$, rare: 1 specimen/ 50 fields of view; P, present: 1 specimen/ >100 fields of view; RW, reworked specimens. The taxonomy of the determined calcareous nannofossil species has been based on Aubry (1984, 1988, 1989, 1990); Perch-Nielsen (1985). The determination of the biostratigraphic events has followed Martini (1971), Fornaciari and Rio (1996), Raffi et al. (2006). Numerical ages of biozone boundaries are given according to Lourens et al. (2004) and Iaccarino et al. (2005).

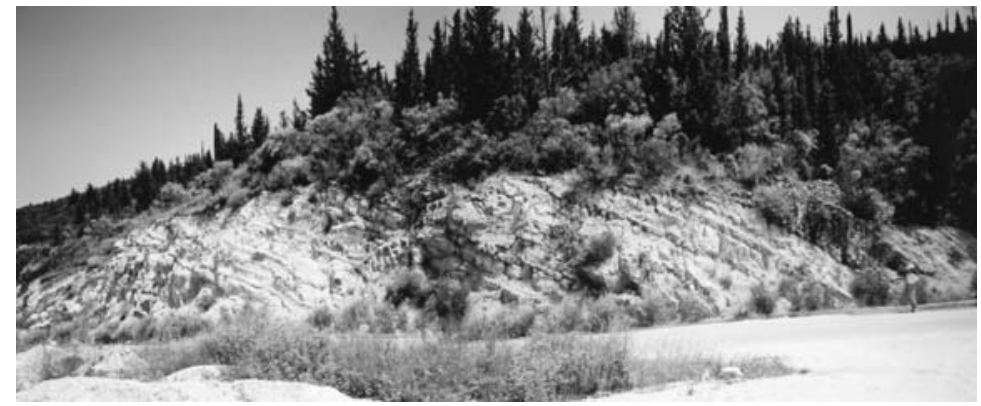

Fig. 2b: The upper part of Spanochorion composite section (molassic deposits).

\section{Biostratigraphic results}

Calcareous nannofossils are abundant throughout the studied sections and were generally well-preserved in all samples. Semiquantitative results of representative taxa are shown in Figs 3, 4.

\subsection{Ag. Vassilios section}

In Ag. Vassilios section, the nannoflora assemblage is dominated by discoasterids and sphenoliths, which provide important biostratigraphic markers in the Miocene. Discoasters mainly contain Dis- 


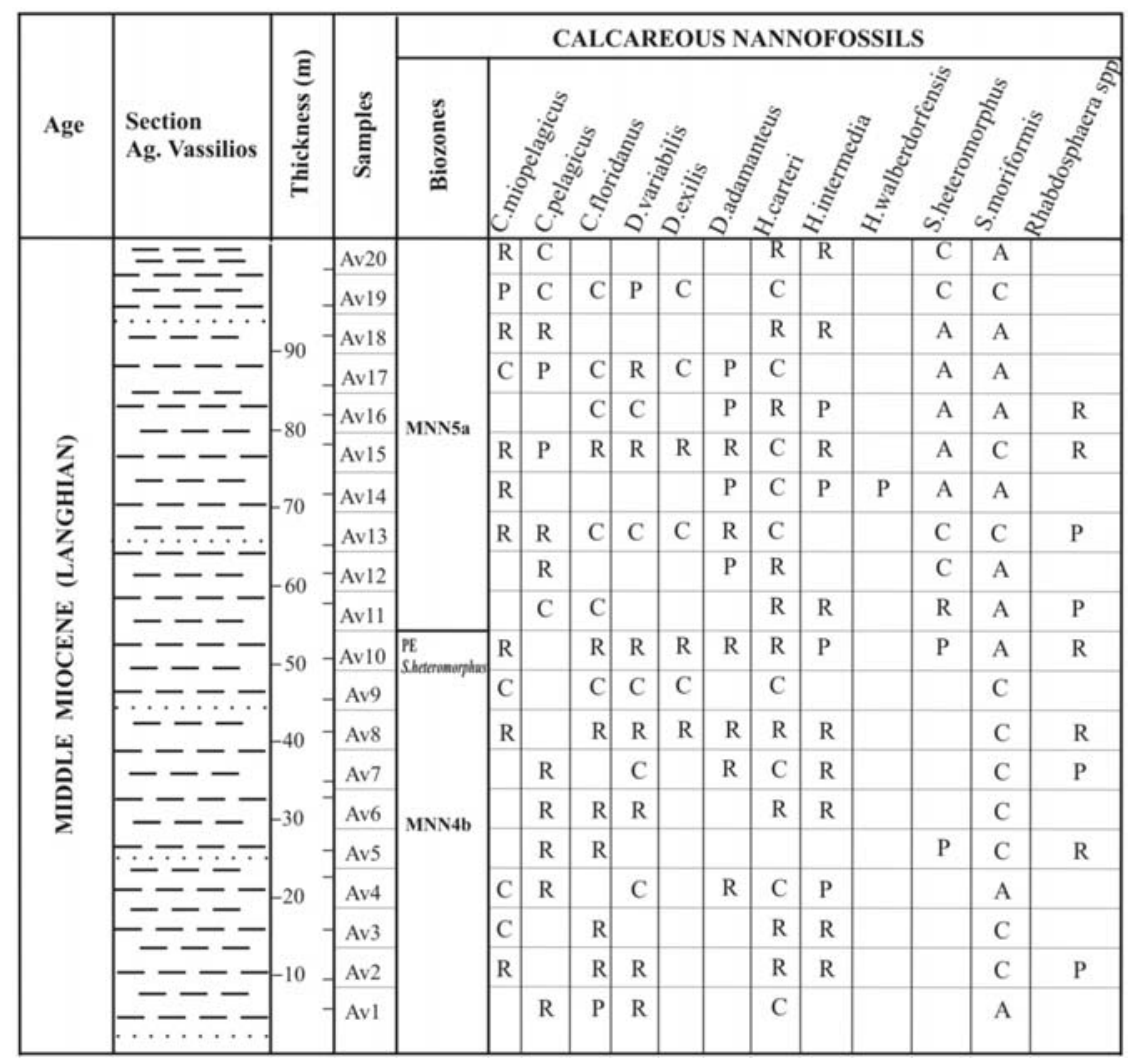

Fig. 3: Lithology, sample location and calcareous nannofossil biostratigraphy of Ag. Vassilios section.

coaster variabilis, D. exilis and D. adamanteus, whereas D. deflandrei is very rare. Sphenolithus spp. include $S$. heteromorphus and S. moriformis.

Placoliths are represented mainly by Coccolithus pelagicus, C. miopelagicus and Cyclicargolithus floridanus. Helicosphaera carteri is also well represented, whereas H. intermedia is scattered and $H$. ampliaperta and $H$. walbersdorfensis are totally absent.

The results reveal the absence of S. heteromorphus at the lower part of the studied section (Fig.3) along with the contemporaneous absence of $H$. ampliaperta and $H$. walbersdorfensis. This indicates the interval of absence or strong reduction of $S$. heteromorphus above the Last Common Occurrence (LCO) of H. ampliaperta and below the First Common Occurrence (FCO) of H. walbersdorfensis, that has been determined by Fornaciari et al. (1996) as Sphenolithus heteromorphus Absence Interval (Paracme) Zone MNN4b, and is correlated with the uppermost part of NN4 (Martini, 1971).

The rest part of the section displays abundant-common $S$. heteromorphus but no trace of $H$. walbersdorfensis, allowing the correlation with the interval between the paracme end of $S$. heteromorphus and the FCO of $H$. walbersdorfensis. This verifies the recognition of Sphenolithus heteromorphus- Helicosphaera walbersdorfensis Interval Subzone MNN5a (Fornaciari et al., 1996) and the lower part of NN5 (Martini, 1971).

The available nannofossil biostratigraphic data enable the dating of Ag. Vassilios section between 


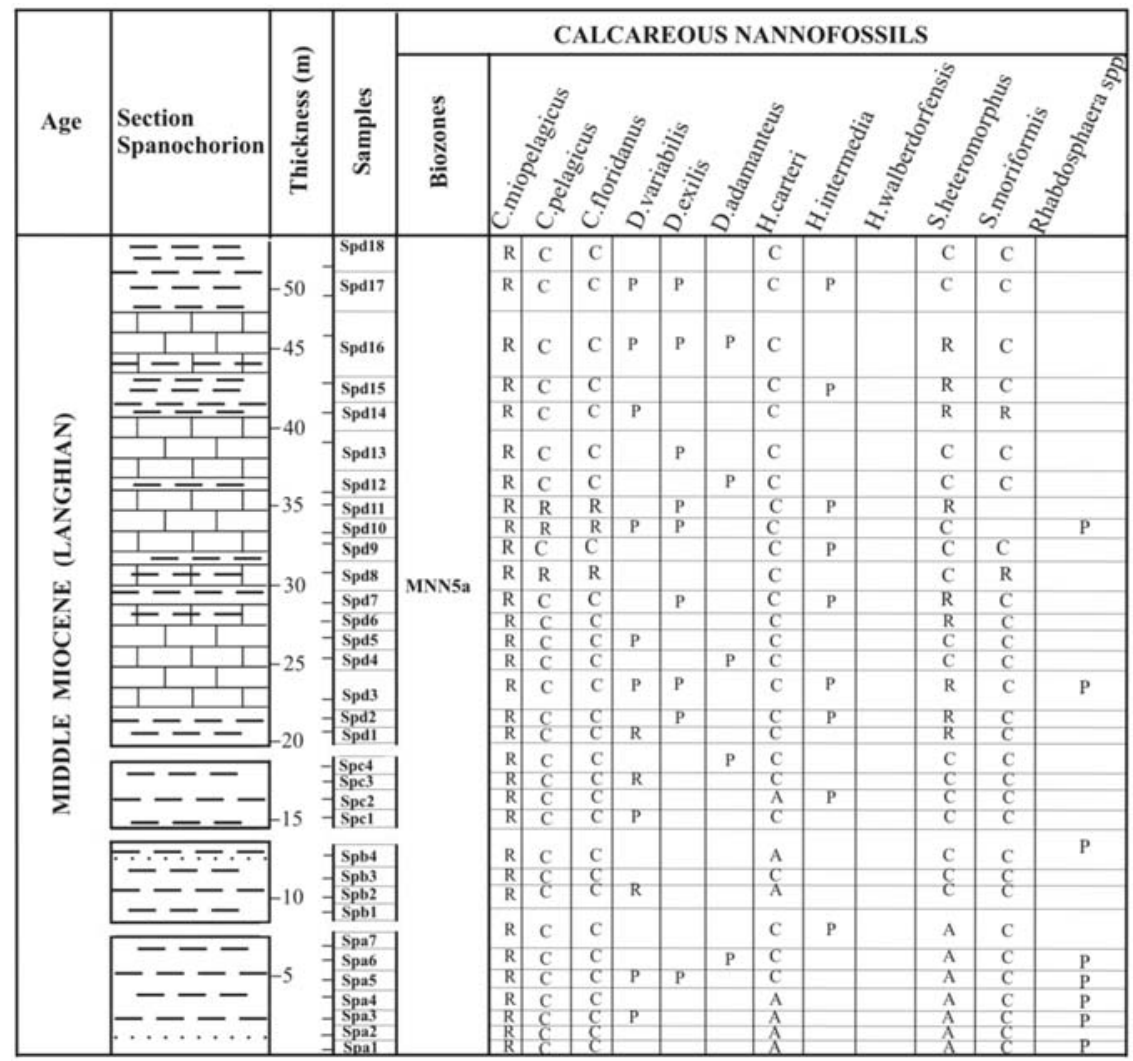

Fig. 4: Lithology, sample location and calcareous nannofossil biostratigraphy of Spanochorion section.

15.974 Ma (PB S. heteromorphus, Iaccarino et al., 2005) and 14.53 Ma (FCO H. walbersdorfensis, Iaccarino et al., 2005). The Paracme End (PE) of S. heteromorphus at $15.5 \mathrm{Ma}$, is located at approximately $55 \mathrm{~m}$ from the base of the section (Fig. 3 ).

\subsection{Spanochorion section}

The nannoflora assemblage of Spanochorion section is marked by the abundant-common presence of S. heteromorphus and the absence of H. ampliaperta and H. walbersdorfensis (Fig. 4). This verifies the recognition of Sphenolithus heteromorphus- Helicosphaera walbersdorfensis Interval Subzone MNN5a (Fornaciari et al., 1996) and the lower part of NN5 (Martini, 1971) that ranges between 15.5 and 14.53 Ma (Iaccarino et al., 2005).

\section{Discussion and conclusions}

Previous stratigraphic data concerning the base of Ag. Vassilios section, were proposed by De Mulder (1975) who dated the turbiditic deposits as Early Miocene (Burdigalian) on the basis of the presence of Globigerinoides altiaperturus, G.trilobus, Globoquadrina dehiscens, Globorotalia peripheroronda and G. praescitula that are associated with N6-N7 planktonic foraminiferal biozones. De Mulder (1975) did not provide any data concerning the biostratigraphic assignment of the top of the section. 


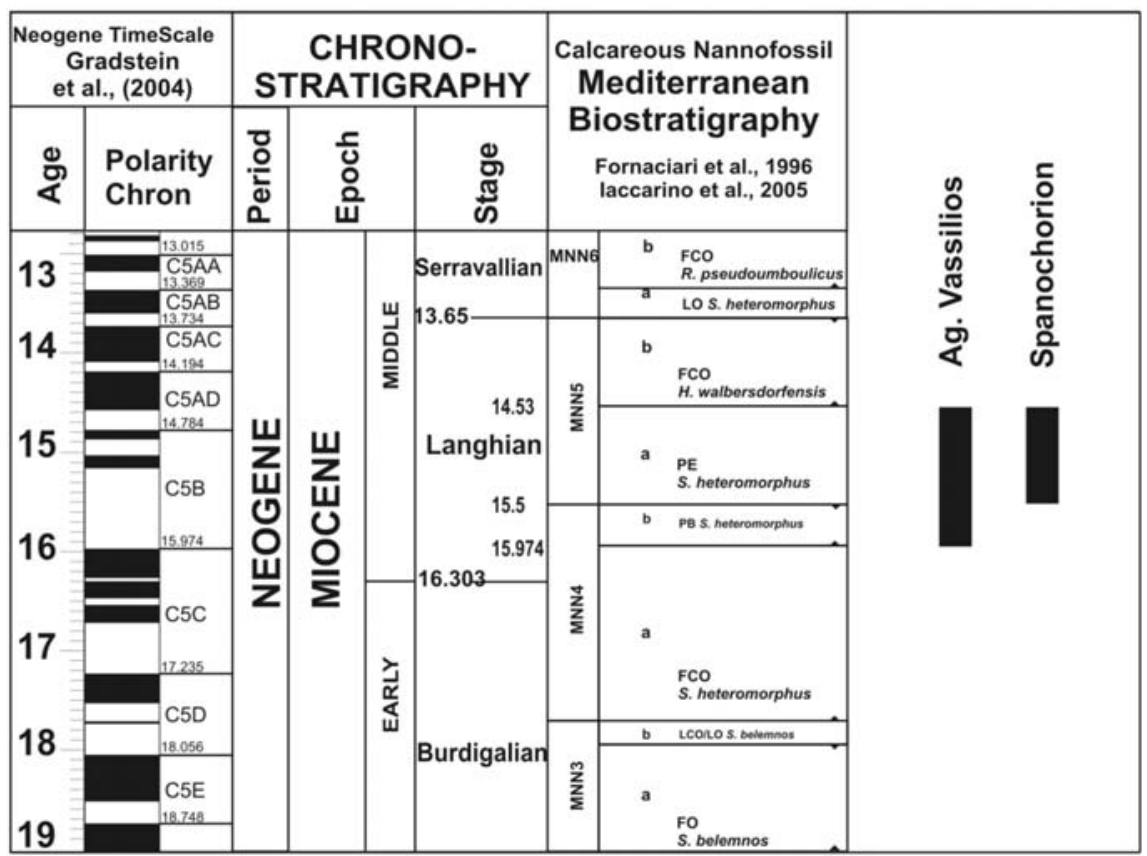

Fig. 5: Biostratigraphic-Chronostratigraphic assignment and age control of Ag. Vassilios and Spanochorion sections on Lefkas Island (ages provided are based on Lourens et al. 2004, Iaccarino et al. 2005).

However IGRS-IFP (1966) and Bizon (1967) suggested that the section may reach as high as the Late Miocene. Our results provide an Early Langhian age (15.974 -14.53 Ma) to the studied Paxos atypical flysch deposits of Ag. Vassilios section.

Overall it seems likely that the duration of Paxos atypical flysch deposition on Lefkas Island spanned the Aquitanian, Bourdigalian (sections Komilio, basal Ag. Vassilios; De Mulder, 1975), Early Langhian (upper Ag. Vassilios section; 15.974 -14.53 Ma, present study), Late Langhian (section Roupakias; Antonarakou et al, 2006), Serravallian (section Kalamitsi; De Mulder, 1975) and ranged at least till the Early Tortonian (section Manassi; 11.54-11.2 Ma, Drinia et al., 2007).

The molassic sediments of NE Lefkas do not reach the Late Miocene. De Mulder (1975) provided evidence for Burdigalian-Langhian dating of several deposits in this area. In particular, Spanochorion section has been assigned to N8 planktonic foraminiferal zone (Late Bourdigalian-Early Langhian) by De Mulder (1975). The present study refined this dating to Early Langhian (15.5 -14.53 Ma). Similar results have been provided from the nearby Asprogerakata section (Antonarakou et al., 2006).

The biostratigraphic results of the present study (Fig. 5) support the hypothesis that the deposition of both the molassic sediments of NE Lefkas Island behind the Ionian thrust and Paxos atypical flysch sequences deposited in front of Ionian thrust, was taking place until at least the Early Langhian times (Fig. 1b).

\section{Acknowledgements}

Funding has been provided by Research Project 70/4/8644 financed by the University of Athens. 


\section{References}

Antonarakou, A., Di Stefano, A., Drinia, H., Lirer, F., Foresi, L., Kontakiotis, G., and Tsaparas, N., 2006. Calcareous Plankton Biostratigraphy and age of the Lower-Middle Miocene deposits of Levkas Island, Ionian Sea, Greece, Geophysical Research Abstracts, 8, 07158.

Aubouin, J. 1959. Contribution a l'étude géologique de la Grèce septentrional: le confins de l' Epire et de la Thessalie. Annales Geologiques des Pays Helleniques, 10, 1-483.

Aubry, M.-P. 1984, 1988, 1989, 1990, 1999. Handbook of Cenozoic Calcareous Nannoplankton, Vol. 15, Micropress, American Museum of Natural History, New York.

Bornovas, J., 1964. Geologie de l'1le de Lefkade, Geol. Geophys. Res., 10 (1), 143pp.

B. P., 1971. The geological results of petroleum exploration in western Greece, Institute of Geology Subsurface Researsh, Athens 10, 73pp.

Cushing, M., 1985. Evoluation structurale de la marge nord-ouest hellenique dans l'ile de Lefkada et ses environs (Greece nord-occidentale), These du 3em cycle, Univ. de Paris-Sud (XI), Centre d'Orsay.

DeCelles, F.G. and Giles, K.A., 1996. Foreland basin systems, Basin Research, 8, 105-123.

De Mulder, E.F., 1975. Microfauna and sedimentary-tectonic history of the Oligo-Miocene of the Ionian Islands and western Epirus (Greece), Utrecht Micropaleontol. Bull., 13, 1-139.

Drinia, H., Antonarakou, A., Kontakiotis, G., Tsaparas, N., Segou, M., and Karakitsios, V., 2007. Paleobathymetric evolution of the Early Late Miocene deposits of the Pre-Apulian zone, Levkas Island, Ionian Sea, Bulletin of the Geological Society of Greece, XXXX, 39-52.

Fornaciari, E., Di Stefano, A., Rio, D., and Negri, A., 1996. Middle Miocene quantitative calcareous nannofossil biostratigraphy in the Mediterranean region, Micropaleontology 42, 37-63.

IGRS - IFP, 1966. Etude geologique de l' Epire (Grece nord - occidentale), Technip., Paris, (306p).

Jacobshagen, V., 1986. Geologie von Griechenland. Berlin: Gebruder Bornträger, 363pp.

Iaccarino S., Premoli Silva I., Biolzi M., Foresi L.M., Lirer F., and Petrizzo M.R., 2005. Practical manual of Oligocene to Middle Miocene Planktonic Foraminifera. Eds. (Biolzi M., Iaccarino S., \& Rettori R.) International School on Planktonic Foraminifera $4^{\circ}$ Course. Perugia 14-18 February. University of Perugia Press.

Karakitsios V., 1992. Ouverture et inversion tectonique du basin Ionien (Epire, Grece), Annales Geologiques des Pays Helleniques, 35 (1), 185-318.

Karakitsios V., 1995. The Influence of Preexisting Structure and Halokinesis on Organic Matter Preservation and Thrust System Evolution in the Ionian Basin, Northwest Greece, AAPG Bulletin, 79 (7), 960-980.

Karakitsios, V., and Rigakis, N., 2007. Evolution and petroleum potential of Western Greece. Journal of Petroleum Geology, 30 (3), 197-218.

Lekkas, E., Danamos, G., and Lozios, S., 2001. Neotectonic structure of Lefkada Island, Bull. Geol. Soc. Greece, XXXIV/1, 157-163.

Lourens, L., Hilgen, F., Shackleton, N. J., Laskar, J., and Wilson, J., 2004. The Neogene period. In: F. M. Gradstein et al., eds, A Geologic Time Scale 2004, p. 409-440, Cambridge University Press.

Martini, E. 1971. Standard Tertiary and Quaternary calcareous nannoplankton zonation. In A. Farinacci (ed.), Proceedings of the Second Planktonic Conference, Roma, Technoscienza, 739-785.

Mirkou, R.M., 1974. Stratigraphie et Géologie de la partie septentrionale de l' île de Zante (Grèce), Annales Geologiques des Pays Helleniques, 26, 35-108.

Nikolaou, C., 1986. Contribution to the study of Neogene and Geological concepts of the Ionian and Preapulian zone and their boundaries in relation to hydrocarbon exploration mainly on 
Strophades, Zakynthos and Cephallonia, PhD thesis, National and Kapodistrian University of Athens, 350 pp., Athens.

Perch-Nielsen, K., 1985. Cenozoic calcareous nannofossils. In: Bolli, H.M., Saunders, J.B. \& PerchNielsen, K. (eds): Plankton Stratigraphy, 427-554. Cambridge Earth Science Series.

Raffi, I., Backman, J., Fornaciari, E., Palike, H., Rio, D., Lourens, L., Hilgen, F., 2006. A review of calcareous nannofossil astrobiochronology encompassing the past 25 million years, Quaternary Science Reviews, 25, 3113-3137.

Renz, C., 1955. Die vorneogene Stratigraphie der normal-sedimentaren Formationen Griechenlands, Institute for Geology and Subsurface Research, $637 \mathrm{pp}$.

Rondoyanni-Tsiambaou, Th., 1997. Les seismes et l'environnement geologique de l'1le de Lefkade, Grece: Passe et Futur. In: Marinos, et al., (Eds.), Engineering Geology and the Environment. Balkema, 1469- 1474.

Sotiropoulos, S. Kamberis, E., Triantaphyllou, M. V., and Doutsos, T. 2003. Thrust sequences in the central part of the External Hellenides, Geological Magazine, 140 (6), 661-668. 